International Journal of Agricultural Policy and Research Vol.10 (1), pp. 1-9, January 2022

Available online at https://www.journalissues.org/IJAPR/

https://doi.org/10.15739/IJAPR.22.001

Copyright (C) 2022 Author(s) retain the copyright of this article

ISSN 2350-1561

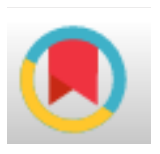

Original Research Article

\title{
Effect of uncontrolled fermentation and soaking on antinutrients of Tacca leontopetaloides (L) Kuntze (Taccaceae) tuber flour
}

Received 28 October, 2021
Collinlaw J. Ndouyang1,2*,
and
Passannet Augustin
Schinzoumka ${ }^{1}$

1Department of Biological
Sciences, Faculty of Technical and
Technological Sciences,
University of Pala, Baore Mine
Road, PO Box 20 Pala, Tchad.
2Department of Food Sciences
and Nutrition, Laboratory de
Biophysics and Food
Biochemistry/Nutrition, ENSAI,
University of Ngaoundere, PO
Box 455 Ngaoundere, Cameroon.

*Corresponding Author
Email: ndouyang@yahoo.fr

Soaking and fermentation are two food technologies that are used by households or agro-industrial establishments. These practices aim at improving food nutritional acceptability and sensorial parameters. Tacca leontopetaloides tuber was used to study alleviation of antinutrients by solubilization and leaching through soaking, or by enzymatic degradation through fermentation. Soaking has lasted $72 \mathrm{hrs}$, and fermentation $48 \mathrm{hrs}$. Chemical methods have been used to determinate antinutrient levels in processed and unprocessed T. leontopetaloides tubers slices. A statistical analysis by means of XLSTAT was purchased for principal components and correlations between variables. Results show that the major antinutrients have exhibited resistance to microbial enzymes during fermentation or to solubilization in water. Levels of most antinutrients have increased instead of lowering when tacca tuber slices were soaked or fermented. The increase of components during soaking and fermentation is linked to the decrease of soluble components in T. leontopetaloides slices. Phytate is an antinutrient which resists to both food technologies, and saponins can be leached by 43.4 \% through soaking or by $50.7 \%$ during fermentation. These powerful antinutrients in $T$. leontopetaloides tuber necessitate food technologies combinations to eliminate them. Further investigations are necessary to succeed in antinutrient levels alleviation in T. leontopetaloides tuber.

Keywords: Food technology, Tacca leontopetaloides, antinutrient, soaking, fermentation.

\section{INTRODUCTION}

Food technology and food engineering are used to develop processes that are useful to nutrient bioavailability. In order to reach that objective, germination, fermentation and soaking are frequently undertaken by users. Chiefly, germination concerns seeds containing high quantity of toxins or antinutrients that are responsible of low acceptability. Enzymes in seeds enhance degradation of antinutrients and break down partial amount of them. For similar objectives, fermentation of food lowers antinutritional content factors (Samia et al., 2005). Thanks to enzymes from bacteria, fermentation is a technology in which the growth and metabolic activities of microorganisms are used to preserve foods (Hasan et al., 2014; Widyastuti and Febrisiantosa, 2014). Because of these beneficial effects, fermented foods and beverages have been an indispensable part of the human diet since ancient times and they remain important in many developing countries where they are an integral part of local cultures and traditions (Borresen et al., 2012; Ansorena and Astiasaran, 2016). The most common groups 
of microorganisms involved in food fermentation are bacteria, yeasts and moulds. But soaking is a process that induces the solubility of molecules in water according to concentration gradient. Usually, vegetable leaves are fermented and bitter tubers undergo soaking.

All these food processes aim at improving food quality (Djeni et al., 2011). For example, complementary foods of young children contain few iron and zinc. The bioavailability of these minerals is reduced by phytates who bind them. The improvement of the nutritional quality of these foods goes with a reduction of phytate content and the possibility to evaluate mineral bioavailability (IcardVernière et al., 2003). Then, it was suggested by Soro et al. (2013) that factors to be taken into account in the infant flours formulated from tubers (yam) and seeds (soya bean) fermented flours must be determined.

Bitter cassava roots (Manihot esculenta Crantz) bleaching frequently used households can be considered as illustration in case of roots and tubers (Djeni et al., 2011; Djina et al., 2017). Many underexploited tuber crops undergo such a food technology. For tuber crops play an important role in food security, nutritional security and climate change adaptation. According to Chintha et al. (2018), these crops are essential components of stable daily diet in many under developed and developing countries around the globe. Fermentation is essentially due to bacteria. Its effect is calculable when the microorganism species is known (Ntsamo et al., 2020). But, in the case of uncontrolled fermentation, many microorganism species can involve in.

Uncontrolled fermentation of Senna obtusifolia leaves (kawal) (Mbaiguinam et al., 2005; Abakar et al., 2019) and that of Hibiscus sabdariffa seeds (Mohamadou et al., 2010; Ane et al., 2016) have been reported. Here, the effect of a single species of bacteria is not appreciated, but the whole. In 2009, Ndouyang et al. have shown the kinectics of Tacca leontopetaloides saponins mobilization in water on a sigmoidal mathematic model. In fact, $T$. leontopetaloides tubers were sliced before using. Later, Ndouyang et al. (2015) adopted a screening method to lower antinutrient levels in T. leontopetaloides slices using heat and water only. Recently, Lakram et al. (2019) tested optimizing the detoxification of argane (Argania spinosa) by using different food technologies such as soaking in cold distilled water and in sodium bicarbonate and citric acid solutions, boiling in distilled water and in sodium bicarbonate and citric acid solutions. Finally, these food technologies are frequently used: boiling, germination, fermentation, soaking. Ndouyang et al. (2014) reported that at low levels in the diet, ingestion of unprocessed tacca reduced the level of LDL-cholesterol and limited digestion of lipids by increasing the fecal lipids. Their experience on rats concluded for ingestion a day at a quantity not higher than $1.34 \mathrm{~g}$ unprocessed tacca per $\mathrm{kg}$ body weight and per day

For the actual research, T. leontopetaloides tuber slices were submitted respectively to an uncontrolled fermentation in an incubator and soaking with drinking water in our laboratory. The present study aims at evaluating the effect of uncontrolled fermentation versus soaking on antinutritional factors in $T$. leontopetaloides tuber slices.

\section{MATERIALS AND METHODS}

\section{Pretreatments of T. leontopetaloides Tubers and production of flour}

Fresh T. leontopetaloides samples were harvested from the wild in the locality of Binder in Western Mayo-Kebbi Region, Chad. Samples were subjected separately to two different processing protocols:

the first being an uncontrolled fermentation of slices without a specific species of microorganism as reported by Abakar et al. (2019). About 100-150 g of samples were incubated in an oven at $38 \pm 0.2^{\circ} \mathrm{C}$ for $48 \mathrm{hrs}$ (FTL48H).

- $\quad$ the second involved soaking of $0.3-0.5 \mathrm{~cm}$ thickness slices. About 100-150 g of samples were soaked in 5 liters of drinking water during $72 \mathrm{hrs}$ (STL).

the third sample was unprocessed slices of tacca tubers (UTL). The tubers were peeled, cleaned, pulped, and $100-150 \mathrm{~g}$ of samples were oven dried.

The soaking and the fermentation time were adopted from traditional household process. In each case, sample was dried for $24 \mathrm{hrs}$ in an electrical convection dryer set at $50^{\circ} \mathrm{C}$ up to a constant weight of sample(Figure 1). In the flour production procedure, samples were ground into flour in a Blender machine (Japan). The sizes flour granule after blended were the same size in every treatment leaving from $12.21 \mu \mathrm{m}$ to $41.43 \mu \mathrm{m}$ having peak at 22.49-26.2 $\mu \mathrm{m}$. Flours were kept at $4{ }^{\circ} \mathrm{C}$ until utilization.

Determinations of the antinutrient levels in $T$. leontopetaloides flour samples were purchased as described recently by Ndouyang et al. (2015, 2018). Briefly, these chemical components were determined and expressed in milligrams per one hundred of dried weight $(\mathrm{mg} / 100 \mathrm{~g}$ of DW).

\section{Total and soluble oxalates}

The total and soluble oxalates were quantified according to the method of Day and Underwood [1986] insoluble oxalates were determined by difference.

\section{Phytates}

The phytates content was determined according to the method of Vaintraub and Lapteva as modified by Gao et al. (2007). Essentially, the time of extraction was prolonged to 16 hours instead of 1 hour; the temperature of centrifugation was reduced to $10{ }^{\circ} \mathrm{C}$, with the introduction of a cleaning stage aimed at improving the phytic acid extraction. Thus, a sample of $0.5 \mathrm{~g}$ was used. The optical density (OD) was read at $500 \mathrm{~nm}$ against distilled water 


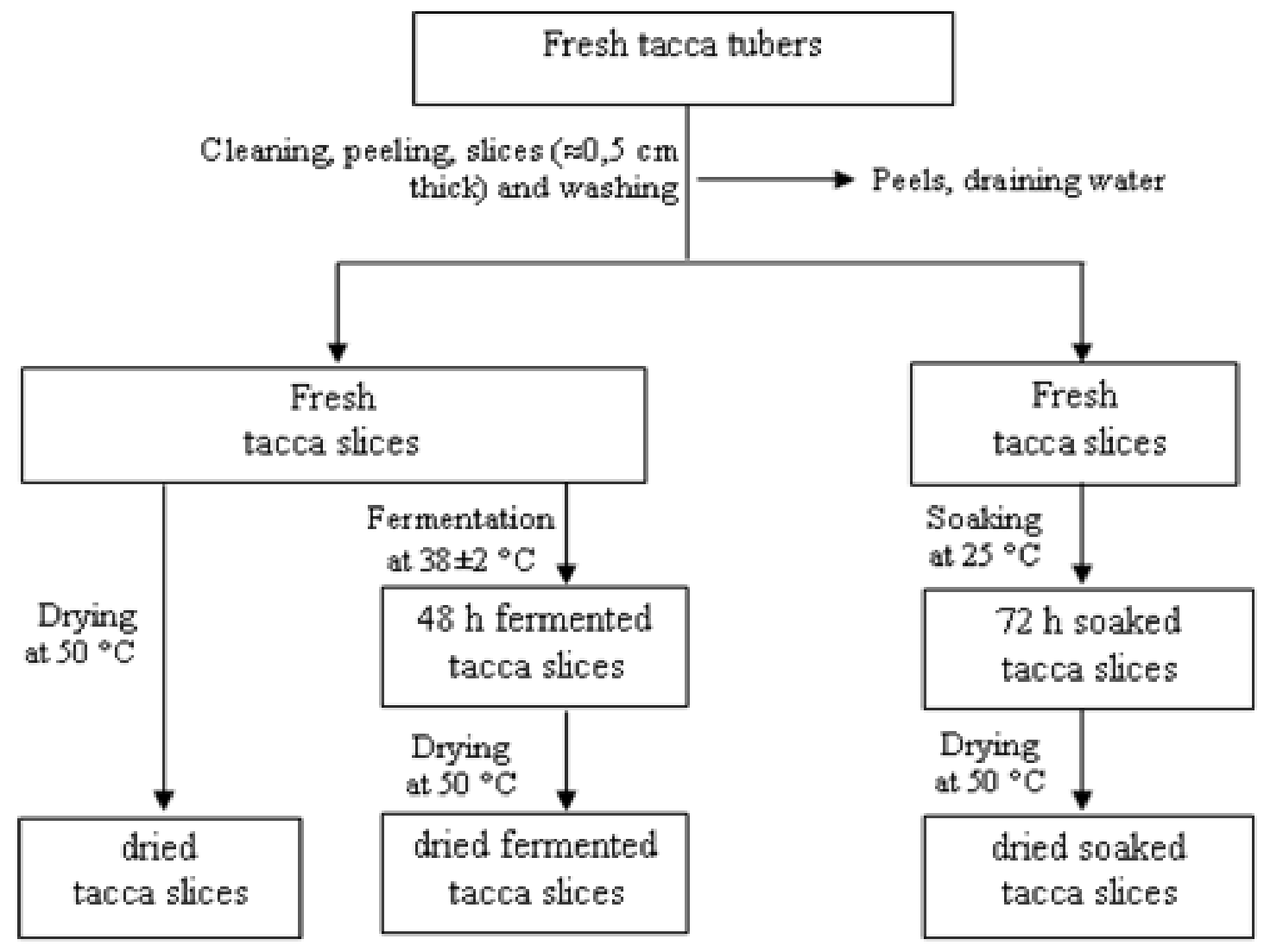

Figure 1: Soaking and fermentation treatments protocols of T. leontopetaloides tubers

against a blank made up distilled water at the place of sample extract. Phytic acid solution concentration from 0 to $40 \mu \mathrm{g} / \mathrm{mL}$ was used as standard.

\section{Total phenolic compounds:}

The total phenolic compounds were quantified in methanolic extract as following the method earlier used by Nguimbou et al. (2013). The results are expressed in gallic acid equivalent (GAE).

\section{Total and condensed tannins}

The determination of total tannins level in $T$. leontopetaloides flours was based on the ability of tannins to combine and precipitate with polyvinyl polypyrrolidone (PVPP) as recently described (Ngatchic et al., 2013). Hydrolysable tannins were determined by difference.

\section{Flavonoids}

The levels of flavonoids in the samples were determined following the method described by Siddiq et al. (2010).

\section{Alkaloids}

The alkaloid content was determined gravimetrically
The alkaloid content was determined gravimetrically (Haborne, 1973) recently used by Adeniyi et al. (2009). Briefly, $5 \mathrm{~g}$ of each sample was weighed using a weighing balance and dispersed into $50 \mathrm{~mL}$ of $10 \%$ acetic acid solution in ethanol. The mixture was well shaken and then allowed to stand for about 4 hrs before it was filtered. The filtrate was then evaporated to one quarter of its original volume on hot a plate. Concentrated ammonium hydroxide was added drop wise in order to precipitate the alkaloids. A pre-weighed filter paper was used to filter off the precipitate and it was then washed with $1 \%$ ammonium hydroxide solution. The filter paper containing the precipitate was dried in an oven at $60{ }^{\circ} \mathrm{C}$ for $30 \mathrm{~min}$, transferred into desiccators to cool and then reweighed until a constant weight was obtained. The constant weight was recorded. The weight of the alkaloid was determined by weight difference of the filter paper and expressed as a percentage of the sample weight analyzed. The experiment was repeated three times for each foodstuff sample and recorded as the average of three replicates.

\section{Cyanides}

Total cyanides were extracted by distillation followed by a colorimetric determination following the method described by Makkar et al. (2007). Essentially, $4 \mathrm{~g}$ of flour sample were introduced into a heating balloon in which $125 \mathrm{ml}$ of 
Int. J. Agric. Pol. Res. 4

Table 1. Effect of the soaking and fermentation conditions on the antinutrient content (mg/100g.DM) of Tacca leontopetaloides flour

\begin{tabular}{lccccc}
\hline Parameters & $\begin{array}{c}\text { Unprocessed } \\
\text { tacca tuber } \\
\text { (UTL) }\end{array}$ & $\begin{array}{c}\text { Soaked tacca } \\
\text { tuber for 72 hrs } \\
\text { (STL72H) }\end{array}$ & $\begin{array}{c}\text { Fermented tacca } \\
\text { tuber for 48 hrs } \\
\text { (FTL48H) }\end{array}$ & $\begin{array}{c}\text { Variation } \boldsymbol{\Delta} \\
\text { STL72H/ } \\
\text { UTL(\%) }\end{array}$ & $\begin{array}{c}\text { Variation } \Delta \\
\text { FTL48H/ UTL } \\
\text { (\%) }\end{array}$ \\
\hline Total oxalates & $318.11 \pm 16.70^{\mathrm{b}}$ & $354.61 \pm 18.61^{\mathrm{b}}$ & $34.55 \pm 1.81^{\mathrm{a}}$ & 11.5 & $\mathbf{- 8 9 . 1}$ \\
Soluble oxalates & $305.25 \pm 17.62^{\mathrm{b}}$ & $296.48 \pm 15.56^{\mathrm{b}}$ & $18.85 \pm 1.81^{\mathrm{a}}$ & -2.9 & $\mathbf{- 9 3 . 8}$ \\
Insoluble oxalates & $12.85 \pm 0.93^{\mathrm{a}}$ & $58.13 \pm 3.05^{\mathrm{b}}$ & $15.71 \pm 0.00^{\mathrm{a}}$ & 352.3 & 22.2 \\
Phytates & $457.97 \pm 18.41^{\mathrm{b}}$ & $351.11 \pm 20.88^{\mathrm{a}}$ & $368.59 \pm 21.39^{\mathrm{a}}$ & -23.3 & -19.5 \\
Phenolics & $82.21 \pm 3.47^{\mathrm{a}}$ & $120.85 \pm 10.93^{\mathrm{b}}$ & $94.39 \pm 6.30^{\mathrm{a}}$ & 47.0 & 14.8 \\
Total tannins & $52.23 \pm 5.80^{\mathrm{a}}$ & $60.55 \pm 14.73^{\mathrm{a}}$ & $46.71 \pm 6.01^{\mathrm{a}}$ & 15.9 & -10.6 \\
Condensed tannins & $29.99 \pm 4.21^{\mathrm{a}}$ & $60.30 \pm 10.78^{\mathrm{a}}$ & $47.67 \pm 6.25^{\mathrm{b}}$ & 101.1 & 59.0 \\
Hydrolysables tannins & $1.02 \pm 0.15^{\mathrm{a}}$ & $0.91 \pm 0.16^{\mathrm{b}}$ & $2.03 \pm 0.23^{\mathrm{b}}$ & -10.8 & 99.0 \\
Flavonoids & $23.54 \pm 0.62^{\mathrm{b}}$ & $16.19 \pm 0.16^{\mathrm{a}}$ & $35.78 \pm 0.23^{\mathrm{c}}$ & -31.2 & 52.0 \\
Alkaloids & $803.85 \pm 7.30^{\mathrm{c}}$ & $453.20 \pm 11.64^{\mathrm{b}}$ & $181.82 \pm 17.50^{\mathrm{a}}$ & $\mathbf{- 4 3 . 6}$ & $\mathbf{- 7 7 . 4}$ \\
Cyanides & $1.20 \pm 0.06^{\mathrm{a}}$ & $1.71 \pm 0.03^{\mathrm{b}}$ & $0.92 \pm 0.15^{\mathrm{a}}$ & 42.7 & -22.7 \\
Saponins & $510.15 \pm 29.67^{\mathrm{b}}$ & $288.55 \pm 11.90^{\mathrm{a}}$ & $251.54 \pm 5.59^{\mathrm{a}}$ & $\mathbf{- 4 3 . 4}$ & $\mathbf{- 5 0 . 7}$ \\
\hline
\end{tabular}

UTL: Unprocessed T. leontopetaloides tuber; STL72H: Soaked T. leontopetaloides tuber for $72 \mathrm{~h}$;

FTL48H: Fermented T. leontopetaloides tuber for $48 \mathrm{~h}$.

distilled water and $2.5 \mathrm{ml}$ of chloroform were added, and the glassware stirred up for homogenization. At the end of the process, the final volume was registered. In this respect, $4 \mathrm{ml}$ of distillate was introduced into a test tube, and $4 \mathrm{ml}$ of the alkaline picrate solution were added, well mixed and heated in a boiling water bath during 5 min to allow the development of the color. The intensity of colour was read at $520 \mathrm{~nm}$ against the blank made up with water. The cyanide content was expressed as mg equivalent $\mathrm{HCN}$ per 100 g dry matter.

\section{Saponins}

Were quantified according to the method of Makkar et al. (2007). Essentially, $1.5 \mathrm{~g}$ of finely crushed and defatted sample was added to $30 \mathrm{ml}$ of $80 \%$ aqueous ethanol for 16 hours, followed by centrifugation at $3000 \mathrm{rpm}$ during 20 min. The supernatant was collected and the residue resuspended in $80 \%$ aqueous ethanol and treated in the same manner as previously. The two supernatants were combined and filtered on coffee filter paper in order to withdraw the possible particles being able to float on the surface. Then, the ethanol was evaporated at $42-45{ }^{\circ} \mathrm{C}$ in Rotavapor, the aqueous phase was centrifuged to withdraw non water-soluble materials before being transferred in a separating funnel for decantation and to undergo two extractions with equal volume to tap the pigments. The precise final volume of each extract was noted. The calibration curve was carried out with a saponin standard (Quillaja bark, Sigma, USA). The absorbance was read at $544 \mathrm{~nm}$ on a visible spectrophotometer UV (UV/VIS SP8001 Spectrophtometer, Axiom, Germany) against a blank. The results were expressed in $\mathrm{mg}$ sapogenins $/ 100 \mathrm{~g}$ dry matter.

\section{Statistical analysis}

Means and standard deviations $( \pm \mathrm{SD})$ were calculated from
3 individual values. One way analysis of variance was tested to detect the effect of treatment on the antinutrients. The significance of an effect was observed for $\mathrm{p}<0.05$, and the Duncan multiple test range was used to compare two means. The link between antinutrients levels in the flour was analyzed using the Spearman rank correlation. The software Statgraphics Plus 5.0 was used for the statistical analysis. Principal component analysis and Pearson correlation was done using the Statbox 6.4 statistical software (Paris, France).

\section{RESULTS}

The results of the present study are presented in the Table 1. The major antinutrients have exhibited resistance to degradation microbial enzymes during fermentation or to solubilization in water. But total oxalates, soluble oxalates, alkaloids and saponins which variations are $-89.1 \%,-93.8$ $\%,-77.4 \%$ and $-50.7 \%$ respectively during fermentation, or in a less measure, alkaloids and saponins in case of soaking where variations are $-43.6 \%$ and $-43.4 \%$ respectively. Most of antinutrients levels have increased instead of lowering when tacca tuber slices are soaked or fermented. However, Lakram et al. (2019) reported that increasing soaking times to 48 hours did not appear to influence saponins leaching. According to Ndouyang et al. (2015), the increase of components during soaking and fermentation is linked to the decrease of soluble components in T. leontopetaloides slices.

When purchasing the principal component analysis, components in TL are separated into two principal components (PC) (Table 2) based on the similarity of their behavior. In fact, PC1 is constituted of phenolics, condensed tannins, hydrolysable tannins, and flavonoids. And, PC2 is constituted of the others. As it is shown in Figure 2, graph of different variables on the principal component 
Table 2. Correlations between variables and factors (PC axis)

\begin{tabular}{|c|c|c|c|c|c|c|c|c|}
\hline \multirow[b]{2}{*}{ Parameters } & \multicolumn{4}{|c|}{ Correlations between variables and factors (PC axis) } & \multicolumn{4}{|c|}{ Contributions of variables (\%) } \\
\hline & PC1 & PC2 & $\begin{array}{c}\text { Variables } \\
\text { associated to } \\
\text { PC2 }\end{array}$ & $\begin{array}{c}\text { Variables } \\
\text { associated to } \\
\text { PC2 }\end{array}$ & PC1 & PC2 & $\begin{array}{c}\text { Variables } \\
\text { associated to PC2 }\end{array}$ & $\begin{array}{c}\text { Variables } \\
\text { associated to } \\
\text { PC2 }\end{array}$ \\
\hline Total oxalates & -0.934 & 0.358 & & Total oxalates & 12.682 & 2.500 & Total oxalates & \\
\hline Soluble oxalates & -0.879 & 0.477 & & Soluble oxalates & 11.234 & 4.442 & Soluble oxalates & \\
\hline Insoluble oxalates & -0.806 & -0.592 & & Insoluble oxalates & 9.455 & 6.829 & Insoluble oxalates & \\
\hline Phytates & 0.100 & 0.995 & & Phytates & 0.145 & 19.318 & & Phytates \\
\hline Phenolics & -0.629 & -0.777 & Phenolics & & 5.763 & 11.781 & & Phenolics \\
\hline Total tannins & -0.986 & -0.169 & & Total tannins & 14.130 & 0.558 & Total tannins & \\
\hline $\begin{array}{l}\text { Condensed } \\
\text { tannins }\end{array}$ & -0.366 & -0.931 & $\begin{array}{l}\text { Condensed } \\
\text { tannins }\end{array}$ & & 1.945 & 16.902 & & $\begin{array}{c}\text { Condensed } \\
\text { tannins }\end{array}$ \\
\hline $\begin{array}{l}\text { Hydrolysables } \\
\text { tannins }\end{array}$ & 0.928 & -0.372 & $\begin{array}{l}\text { Hydrolysables } \\
\text { tannins }\end{array}$ & & 12.532 & 2.701 & $\begin{array}{l}\text { Hydrolysables } \\
\text { tannins }\end{array}$ & \\
\hline Flavonoids & 0.996 & -0.09 & Flavonoids & & 14.429 & 0.157 & Flavonoids & \\
\hline Alkaloids & -0.482 & 0.876 & & Alkaloids & 3.384 & 14.973 & & Alkaloids \\
\hline Cyanides & -0.974 & -0.226 & & Cyanides & 13.804 & 0.995 & Cyanides & \\
\hline Saponins & -0.185 & 0.983 & & Saponins & 0.497 & 18.846 & & Saponins \\
\hline
\end{tabular}

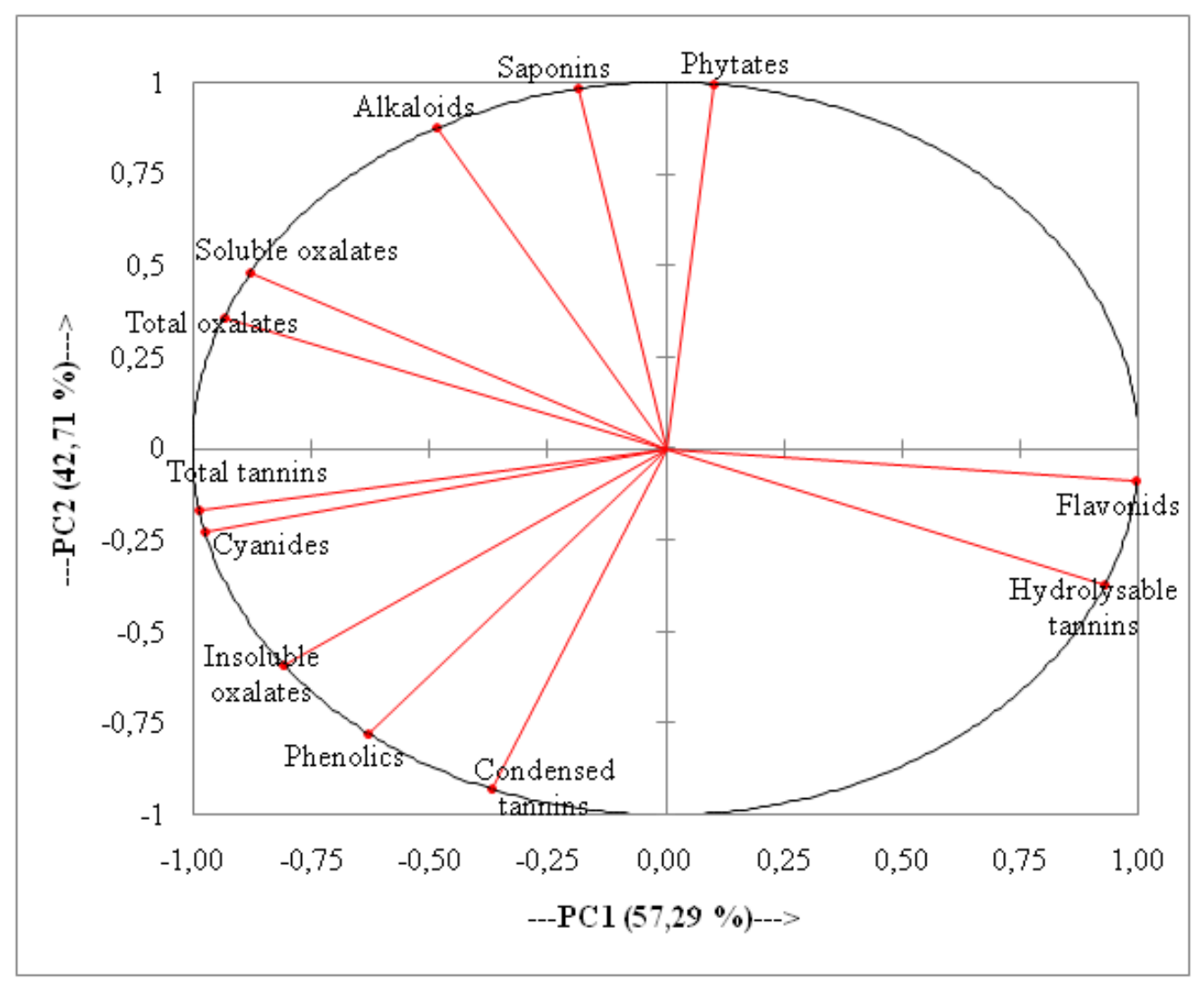

Figure 2: Correlation circle of different variables on the principal component axis

correlation circle is suitable. Components are well distributed and reveal that correlation is normal. It appears clear that experimental results showed a significant difference between the processed tacca tuber and the unprocessed one in terms of dry matter. The methods used for detoxification, i.e., soaking and fermentation, increased antinutrient levels. The same observation was reported about detoxification of Argania spinosa (Lakram et al., 2019). Correlation graph of different variables on the principal component axis is indicated (Figure. 2).

The last part of the presentation of the results is constituted of the contributions of variables (Table 2) and the graph of different flours and variables on the principal component axis (Figure 3). In Table 2, contributions of variables revealed that a lot of components are linked to 
Int. J. Agric. Pol. Res. 6

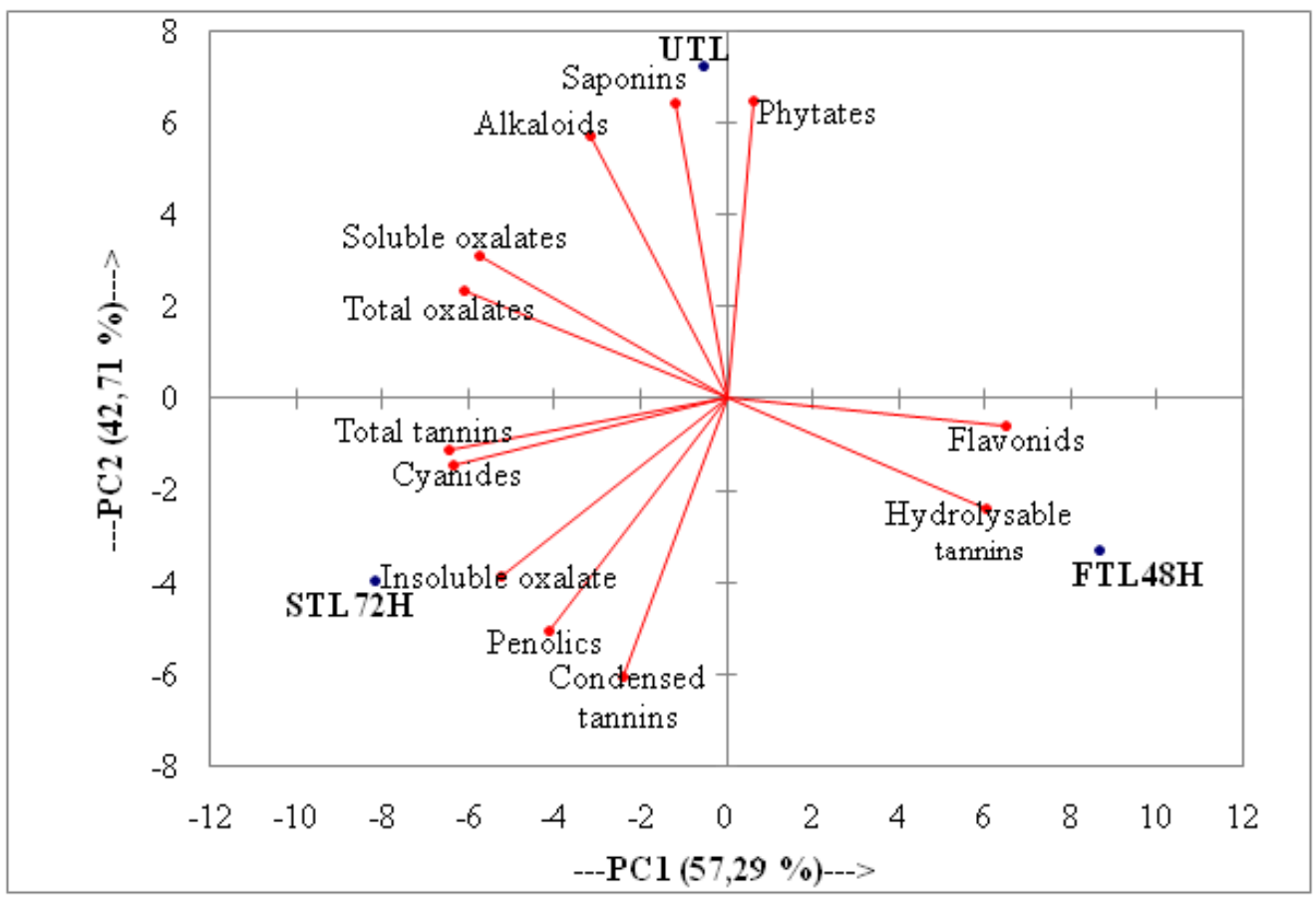

Figure 3. Graph of different flours and variables on the principal component axis

The different flours are represented by blue points.

Table 3. Contributions of observations (\%)

\begin{tabular}{lll}
\hline & PC1 & PC2 \\
\hline UTL & 0,188 & 66,479 \\
STL72H & 46,843 & 19,824 \\
FTL48H & 52,969 & 13,698 \\
\hline
\end{tabular}

PC1. But, phytates phenolics, condensed tannins, alkaloids, saponins are linked to PC2. If contributions of observations are considered, unprocessed sample UTL $(66,479 \%)$ refers to PC2; and the two processed samples, STL72H (46,843\%) and FTL48H (52,7\%), we find that the two processed samples refer to PC1.

\section{DISCUSSION}

Fermented and soaked foods have health benefits. Studies showing the relationship between such foods and health benefits are numerous (Şanlier et al., 2017). Let us cite only nutrient bioavailability, improvements of food digestion and of acceptability. T. leontopetaloides tuber is bitter because of saponin high level (Ndouyang et al., 2009; Ndouyang et al. 2015). When considering correlations between variables and factors (PC axis) (Table 2), oxalates, phytates, tannins, alkaloids, cyanides and saponins constitute fixed to PC2. These components are harmful to in vivo food digestion. In fact, saponins are harmless at $1 \%$ and irritating at 5\% (Fenwick and Oakenfull, 1983). At $1.5 \%$, saponins may also damage the mucosa of the digestive tract (Francis et al., 2002). Ndouyang et al. (2014) reported saponin high and phytate levels in $T$. leontopetaloides. They have shown by the same way the effect of unprocessed tacca tuber on rat growth (Rattus norvegicus L.). On one hand, positive nutritional effects of specific saponins such as hypocholesterolemic effects and improvement of growth in various animal species have also been reported. On the other hand, various studies also demonstrated the toxicity of unprocessed tacca related to saponins. In fact rats rejected food with phytates represented $0.004 \%$ to $0.008 \%$ dry food while saponins varied from 0.003 to $0.05 \%$ dry food. Although the levels of phytates and saponins were low in the isoenergetic food, the rats did not accept them either due to the bitterness or the toxicity they induced. The alleviating of phytate and saponins levels by fermentation and soaking would lead to good acceptability of tacca tuber.

Processing by fermentation of tacca tubers slices appears with interest in lowering oxalates, alkaloids and saponins content by $-89.1 \%,-77.4 \%$ and $-50.7 \%$ respectively during 48 hours. Soaking appears less efficient with antinutrient lowering rate at $-43.6 \%$ for alkaloids and $-43.4 \%$ for saponins. The effective antinutrient decreasing by 
Table 4. Effect of the soaking and fermentation conditions on the antinutrients content (mg/100g.DW) of Tacca leontopetaloides

\begin{tabular}{lcc}
\hline & \multicolumn{2}{c}{ Principal components } \\
\cline { 2 - 3 } & PC1 & PC2 \\
\hline Eigen value & 6.875 & 5.125 \\
Variance (\%) & 57.291 & 42.709 \\
\% cumulated & 57.291 & 100.000 \\
\hline
\end{tabular}

Table 5. Pearson rank correlation matrix between the residual antinutrients levels in Tacca leontopetaloides flours

\begin{tabular}{|c|c|c|c|c|c|c|c|c|c|c|c|c|}
\hline Variables & 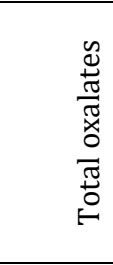 & 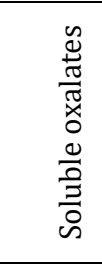 & 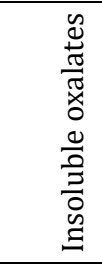 & 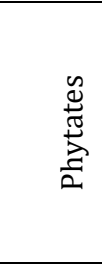 & $\begin{array}{l}: 0 \\
: 0 \\
\frac{0}{0} \\
\frac{0}{0}\end{array}$ & 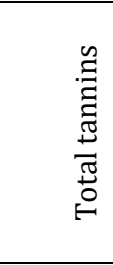 & 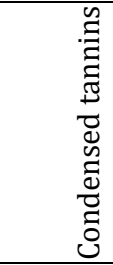 & 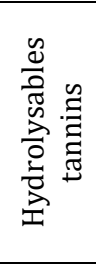 & $\begin{array}{l}\frac{y}{0} \\
0 \\
0 \\
0 \\
\frac{\pi}{I}\end{array}$ & $\frac{\sqrt[n]{0}}{\frac{0}{\pi}}$ & $\frac{\mathscr{d}}{00}$ & 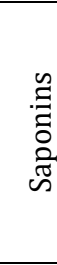 \\
\hline Total oxalates & 1 & & & & & & & & & & & \\
\hline Soluble oxalates & 0.991 & 1 & & & & & & & & & & \\
\hline Insoluble oxalates & 0.541 & 0.426 & $\begin{array}{l}1 \\
-\end{array}$ & & & & & & & & & \\
\hline Phytates & 0.263 & 0.387 & 0.669 & $\begin{array}{l}1 \\
-\end{array}$ & & & & & & & & \\
\hline Phenolics & 0.310 & 0.182 & 0.967 & $\begin{array}{c}0.836 \\
-\end{array}$ & 1 & & & & & & & \\
\hline Total tannins & 0.860 & $\begin{array}{c}0.786 \\
-\end{array}$ & 0.895 & $\begin{array}{c}0.266 \\
-\end{array}$ & 0.752 & 1 & & & & & & \\
\hline Condensed tannins & 0.008 & 0.123 & 0.845 & 0.963 & 0.953 & 0.518 & 1 & & & & & \\
\hline $\begin{array}{l}\text { Hydrolysable } \\
\text { tannins }\end{array}$ & ${ }_{-}^{-}$ & $\begin{array}{c}- \\
0.993 \\
-\end{array}$ & $\begin{array}{c}- \\
0.528 \\
-\end{array}$ & 0.278 & $\begin{array}{c}- \\
0.295 \\
-\end{array}$ & -0.852 & $\begin{array}{c}0.007 \\
-\end{array}$ & 1 & & & & \\
\hline Flavonoids & 0.999* & 0.918 & $\begin{array}{c}0.750 \\
-\end{array}$ & 0.010 & $\begin{array}{c}0.557 \\
-\end{array}$ & -0.966 & 0.999* & $\begin{array}{c}0.958 \\
-\end{array}$ & $\begin{array}{l}1 \\
-\end{array}$ & & & \\
\hline Alkaloids & 0.764 & 0.842 & 0.129 & $\begin{array}{c}0.824 \\
-\end{array}$ & 0.377 & 0.327 & -0.639 & $\begin{array}{c}0.774 \\
-\end{array}$ & $\begin{array}{c}0.559 \\
-\end{array}$ & 1 & & \\
\hline Cyanides & 0.829 & 0.748 & $\begin{array}{c}0.919 \\
-\end{array}$ & 0.322 & $\begin{array}{c}0.789 \\
-\end{array}$ & 0.998* & 0.566 & $\begin{array}{c}0.820 \\
-\end{array}$ & $\begin{array}{c}0.950 \\
-\end{array}$ & 0.272 & $\begin{array}{l}1 \\
-\end{array}$ & \\
\hline Saponins & 0.524 & 0.631 & 0.432 & 0.959 & 0.647 & 0.016 & -0.847 & 0.537 & 0.272 & 0.950 & 0.042 & 1 \\
\hline
\end{tabular}

fermentation processing more than that by soaking processing is due to fermentable components of the tuber that lead to degradation of most organic components. But phytate resists to fermentation and to soaking. Meanwhile, the unprocessed tacca (UTL) belongs to PC2, and STL72H and FTL48H to PC1 (Table 3). Nevertheless, each treatment has positive or negative effect on tacca tuber slices.

The first step in the PCA analysis is the identification of the number of significant axes, called principal components (PC). It is generally believed that principal components with eigen value higher or equal to 1 are significant. Based on this, 2 principal components, PC1 and PC2 were revealed following the execution of principal components analysis (PCA) of the data Table 4. All the antinutrients are separated into two groups according to their behavior related to correlations between variables.

At last, the Pearson rank correlation matrix between the residual antinutrients levels in Tacca leontopetaloides flours (Table 5) exhibited three negative significant correlations. The negative ones show leaching of nutrients when others are being accumulated $(r<0)$. But the same antinutrients are positively correlated when solubilization or degradation by fermentation of soaking decrease or increase together. Unfortunately, saponins and phytate have positive correlation not statistically significant.

\section{Conclusion and recommendations}

Fermentation could be more efficient in reducing oxalate than soaking. Although bioactive products derived from fermented foods, however fermentation and soaking of tacca tuber provide minor profit because of the saponins and phytate which remain in high levels. Good processing must reduce their content in food in order to bioactive 
products derived from fermented foods and/or soaking. Nevertheless, further studies are necessary to find out a safety system with good acceptability and nutrient bioavailability.

\section{Acknowledgements}

Authors of this article are grateful to ENSAI, University of Ngaoundere (Cameroon).

\section{Conflict of interests}

The authors declare no conflict of interest whatsoever.

\section{REFERENCES}

Abakar IL, Guira F, Tapsoba F, Zongo C, Abdoullahi HO, Tidjani A et Savadogo A (2019). Le Kawal, un condiment à base de feuilles fermentées de Senna obtusifolia: technologies et valeurs nutritionnelles. Afr. J. Food Agric. Nutr. Dev.; 19(2): 14244-14260. Crossref

Adeniyi SA, Orjiekwe CL, Ehiagbonare JE (2009). Determination of alkaloids and oxalates in some selected food samples in Nigeria. African J. Biotech. 8(1):110-112.

Ansorena D, Astiasar I (2016). Fermented foods: Composition and health effects encyclopedia of food and health (pp.649-55).Oxford: Academic Press.Crossref

Borresen EC, AJ Henderson, A Kumar, TL Weir and EP Ryan (2012). Fermented foods: patented approaches and formulations for nutritional supplement at ion and health promotion. Recent Patents on Food, Nutrition \& Agriculture 4(2):134-40. Crossref

Christèle IV, Greffeuille V, Caporiccio B, Trèche S, Besançon $P$ (2003). Effects of soaking of cereal and legume seeds and flours on phytate content and Phy/Fe and Phy/Zn molar ratios. 2nd International Workshop, Food-based approaches for a healthy nutrition, Ouagadougou, 23-28 / $11 / 2003$.

Day RA, Underwood AL. Quantitative analysis. 5th ed. Prentic-Hall publication; 1986.

Djeni NT, N'Guessan KF, Toka DM, Kouame KA, Dje KM (2011). Quality of attieke (a fermented cassava product) from the three main processing zones in Côte d'Ivoire. Food Research International, 44: 410-416.

Djina Y, Dan CG, Ahi AP, Gonnety TJ, Amani NG and Kouamé LP (2017). Effect of storage in pit after bleaching of cassava roots (Manihot esculenta Crantz) on functional and sensory characteristics. Journal of Global Biosciences, 6(6): 5095-5105.Crossref

Fenwick DE and Oakenfull D (1983). Saponin content of food plants and some prepared foods. J. Sci Food Agric., 34:186-191. Crossref

Francis G, Kerem Z, Makkar HPS and Becker K (2002). The biological action of saponins in animal systems: A review. British J. Nutr., 88:587-605.Crossref

Gao Y, Shang C, Saghai MA, Biyashev RM, Grabau EA, Kwanyuen P, Burton JW, Buss GR(2007). A modified colorimetric method for phytic acid analysis in soybean. Crop Sci. 47:1797-1803.Crossref

Hasan MN, Sultan MZ, and Mar-E-Um M (2014). Significance of Fermented Food in Nutrition and Food Science. J. Sci. Res., 6 (2): 373-386. Crossref

Lakram N, En-Nahli Y, Zouhair FZ, Moutik S, Kabbour R, El Maadoudi EH, Bendaou M, El Housni A and Naciri M (2019). The impact of optimizing the detoxification of argane (Argania spinosa) press cake on nutritional quality and saponins levels. Iranian Journal of Applied Animal Science, 9(2): 235-246.

Makkar HPS, Siddhuraju P, Becker K (2007). Plant secondary metabolites. Methods Mol Biol., 393:67111.Crossref

Mbaiguinam M, Mahamout Y, Mianpereum T and D Bernard (2005). Constituents of Kawal, fermented Cassia obtusifolia leaves, a traditional food from Chad. Afr. J. Biotechnol.; 4:1080-1083.

Mohamadou BA, Mbofung CMF and Thouvenot D (2010). Characterization of some atypical lactic acid bacteria associated with the fermentation of Hibiscus sabdariffa seeds. African J. Microbiol. Res., 4(24): 2655-2660.

Ndouyang CJ, Ejoh AR, Aboubakar, Facho B, Njintang YN, Mohammadou BA, Mbofung CM (2009). Standardisation de la solubilisation des saponines de Tacca leontopetaloides (L.) Kuntze, tubercule non conventionnel. Revue de génie industriel $3: 33-39$.Crossref

Ndouyang CJ, Nguimbou RM, Njintang YN, Scher J, Facho B, Mbofung CMF (2014). In Vivo Assessment of the Nutritional and Subchronic Toxicity of Tacca leontopetaloides (L.) Tubers. Scholars Academic Journal of Pharmacy, 3(1):53-60. DOI: https://www.researchgate.net/publication/295562770.

Ndouyang CJ, Njintang YN, Scher J, Facho B, Mbofung CM F (2015). Effect of processing method on the antinutrient content of Tacca leontopetaloides (L.) Kuntze flour. British J. Appl. Sci. Technol., 5(3):258-269.

Ngatchic TJM, Njintang NY, Oben JE, Mbofung CMF (2013). Protein quality and antigrowth effect of protein isolate of Mucuna (Mucuna pruriens) and Canavalia (Canavalia ensiformis) seeds. School Acad J Biosci.; 1(5):183-191.

Nguimbou RM, Njintang NY, Makhlouf H, Gaiani C, Scher J, Mbofung CMF (2013). Effect of cross-section differences and drying temperature on the physicochemical, functionaland antioxidant properties of giant taro flour. Food Bioprocess Tech.; 6:1809-1819.Crossref

Ntsamo TMB, Mohammadou BA, Sokamte AT, Njintang NY, Tatsadjieu LN (2020). Effect of Fermentation Using Lactobacillus plantarum A6 on the Physicochemical and Functional Properties of Precooked Sorghum bicolor and Voandzeia subterranea Blended Flour. Hindawi, Int. J. Food Sci., Article ID 9234083, 15 pages; $\underline{\text { Crossref }}$

Samia M, Abdel R, Elfadil EB and Ndullahi HET (2005). Effect of fermentation on antinutritional factors and $\mathrm{HCl}$ extractability of minerals of pearl millet cultivars. J. food Technol., 3(4):516-522.

Siddiq M, Rav R, Harte JB, Dolan KD (2010). Physical and functional characteristics of selected dry bean (Phaseolus 
vulgaris (L.) flours. LWT-Food Sci Technol.; 43:232237. Crossref

Soro S, Konan G, Elleingand E, N'guessan DE, Koffi (2013). Formulation d'aliments infantiles à base de farines d'ignames enrichies au soja. African J. Food, Agriculture, Nutrition and Developpement, 13(5):8313-8339. Crossref

Thongam CA, Rocky T, M SS, Jenita T, Sanasam SS (2016). Hibiscus sabdariffa - A natural micronutrient source. Int. J. Adv. Res. Biol. Sci. 3(4): 243-248.

Widyastuti Y, Febrisiantosa A (2014). The role of lactic acid bacteria in milk fermentation. Food and Nutrition Sciences, 5(04):435-442. 다ossref 